\section{In Vitro Rooting and Subsequent Survival of Two Clones of a Cold-tolerant Eucalyptus grandis $\mathbf{X}$ E. nitens Hybrid}

\author{
M.E. Oscar Mokotedi, M. Paula Watt, and Norman W. Pammenter \\ School of Life and Environmental Sciences, George Campbell Building, \\ University of Natal, Durban 4041, South Africa
}

\author{
Felicity C. Blakeway \\ Mondi Forests, P.O. Box 12, Hilton 3245, South Africa
}

Additional index words. auxin, hardening-off, light intensity, mineral nutrients, micropropagation, temperature

\begin{abstract}
Multiple shoots of two Eucalyptus grandis Hill ex Maid. x E. nitens (Deane \& Maid.) Maid. clones (GN121 and GN107) generated from axillary buds were used for in vitro rooting studies. The highest rooting rates in clones GN121 (75\%) and GN107 (65\%) were achieved on modified 1/4-strength Murashige and Skoog (MS) (1962) medium $\left(\mathrm{Ca}^{2+}\right.$ and $\mathrm{Mg}^{2+}$ levels as for 3/4-strength $\left.\mathrm{MS}\right), 0.5 \mu \mathrm{M}$ IBA, $0.4 \mu \mathrm{M}$ biotin, $0.2 \mu_{\mathrm{M}}$ calcium pantothenate, $0.04 \mathrm{~m}$ sucrose and $0.4 \%(\mathrm{w} / \mathrm{v})$ Gelrite ${ }^{\circledR}$. The optimal culture conditions were an initial 72-h dark incubation period followed by a 16-hour photoperiod at a photosynthetic photon flux density $(P P F D)$ of $37 \mu \mathrm{mol} \cdot \mathrm{m}^{-2} \cdot \mathrm{s}^{-1}$ and $23{ }^{\circ} \mathrm{C}$ day/ $21^{\circ} \mathrm{C}$ night for 7 days, after which the $P P F D$ and temperature were increased to 66 $\mu \mathrm{mol} \cdot \mathrm{m}^{-2} \cdot \mathrm{s}^{-1}$ and $27^{\circ} \mathrm{C}$ day $/ 21^{\circ} \mathrm{C}$ night for 18 days. Plantlets were acclimatized with survival rates of $78 \%$ for GN121 and $58 \%$ for GN107 after 28 days. Chemical name used: indole-3-butyric acid (IBA).
\end{abstract}

Hybrids of Eucalyptus grandis such as $E$. grandis $\times$ E. macarthurii Deane et Maid., E. grandis $\mathrm{x}$ E. urophylla S.T. Blake, and $E$. grandis $\mathrm{x} E$. nitens are important for plantations in cool and dry marginal areas in South Africa, where other eucalypts cannot be successfully grown (Denison and Kietzka, 1993). However, their commercial clonal propagation is difficult, as both macrocuttings and shoots produced in vitro do not root readily (Jones and van Staden, 1994; Le Roux and van Staden, 1991a, 1991b). This has been attributed to the tendency of the shoots to form large amounts of callus at the base (Le Roux and van Staden, 1991a), limiting efficient absorption of water and nutrients (Martin, 1985).

Rooting of woody forest tree species under in vitro conditions is genotype-dependent. Different species, hybrids, and even different clones from the same parental stock may require different culture conditions, as illustrated by the variety of published protocols for rooting microcuttings of Eucalyptus species and hybrids (Furze and Cresswell, 1985; Le Roux and van Staden, 1991a, 1991b; Rasmussen, 1991; Willyams et al., 1992).

\footnotetext{
Received for publication 13 July 1999. Accepted for publication 8 Feb. 2000. This work was supported by grants from the National Research Foundation, Mondi Forests and the Univ. of Natal Research Fund. The cost of publishing this paper was defrayed in part by the payment of page charges. Under postal regulations, this paper therefore must be hereby marked advertisement solely to indicate this fact.
}

Blomstedt et al. (1991) found that the frequency of rooting E. regnans F. Muell. in vitro was higher and callusing was prevented when a high IBA pulse $(98 \mu \mathrm{M}$ for $7 \mathrm{~d}$ in the dark) was applied instead of continual maintenance on $5 \mu \mathrm{M}$ IBA. When Le Roux and van Staden (1991a) employed 9.8 $\mu$ M IBA throughout rooting of a clone of $E$. grandis $\times E$. macarthurii, plants with roots developed from callus at basal ends of shoots did not survive the hardening-off period. These data suggest that vascular connections between the roots and the stem do not form if the proliferation of callus occurs before root initiation.

Although protocols are now available for efficient in vitro rooting of clones of $E$. grandis $\mathrm{x}$ E. macarthurii (Le Roux and van Staden, 1991a) and E. grandis $\times$ E. urophylla (Jones and van Staden, 1994), none has been established for $E$. grandis $\times$ E. nitens clones. However, these hybrids may be the most desirable for afforestation in dry, cold areas, as they have a higher water-use efficiency than some other hybrids of $E$. grandis (February et al., 1995). Therefore, the aim of the present study was to investigate the in vitro rooting requirements of two clones of the cold-tolerant $E$. grandis $\mathrm{x} E$. nitens hybrid.

\section{Materials and Methods}

Establishment of shoot cultures. Shoot cultures of $E$. grandis $\times$ E. nitens $(\mathrm{GN})$ (clones 121 and 107) were initiated in vitro from nodal explants of cutting-derived 1-year-old plants obtained from Mountain Home Laboratory,
Mondi Forests (KwaZulu-Natal, South Africa). These parent plants were maintained in the greenhouse at the University of Natal, Durban (lat. $29^{\circ} 52^{\prime} \mathrm{S}$, long. $30^{\circ} 59^{\prime} \mathrm{E} ; 25^{\circ} \mathrm{C}$ day $/ 18^{\circ} \mathrm{C}$ night) and sprayed with fungicides and fertilizers twice weekly. Two mixtures of fungicides were used. The first, a mixture of $0.2 \%$ (w/v) manganese ethylenebis (dithiocarbamate) (polymeric) complex with zinc salt (mancozeb; Efekto, Johannesburg, South Africa) and $0.1 \%$ (v/v) tetrachloroisopthalonitrile (chlorothalonil; Shell S.A., Johannesburg, South Africa) was applied as a foliar spray. The second, a mixture of $0.1 \%$ (w/v) $N$-propyl-N-[2-(2,4,6-trichlorophenoxy) ethyl]imidazole-1-carboxyamide (prochloraz; Hoechst Schering AgrEvo, Johannesburg, South Africa) and $0.125 \%(\mathrm{w} / \mathrm{v}) 1 H-1,2,4-$ triazol-3-ylamine (triazole; Bayer, Johannesburg, South Africa) was applied as a soil spray. The fertilizers were $0.25 \%(\mathrm{v} / \mathrm{v})$ trace element solution $(0.32 \mathrm{M} \mathrm{Fe}, 0.06 \mathrm{M} \mathrm{Cu}, 0.03 \mathrm{M} \mathrm{Zn}, 0.09$ м B, and 0.004 м Mo) (Trelmix ${ }^{\circledR}$; Hubers, Pietermaritzburg, South Africa), applied as a foliar spray, and $0.1 \%(\mathrm{w} / \mathrm{v})$ Mondi Orange ${ }^{\circledR}$ $1 \mathrm{~N}-2 \mathrm{P}-1 \mathrm{~K}$ (Harvest Chemicals, Johannesburg, South Africa), applied as a soil spray.

Freshly sprouted lateral branches (10-20 $\mathrm{cm}$ long) with preformed apical and axillary buds were harvested and surface sterilized in $0.02 \%$ (w/v) $\mathrm{HgCl}_{2}$ plus one drop Tween-20 $0^{\circledR}$ detergent (Associated Chemical Enterprises, Johannesburg, South Africa) for $10 \mathrm{~min}$ and then rinsed several times in sterile distilled water. The material was soaked for $10 \mathrm{~min}$ in $1 \%(\mathrm{w} / \mathrm{v})$ calcium hypochlorite and rinsed several times in sterile distilled water. The sterile branches were trimmed into nodal sections (3-3.5 cm in length), each containing two leaves cut to a third of their original length. Shoot proliferation was induced in multiplication medium comprised of MS nutrients (Murashige and Skoog, 1962; Highveld Biological, Durban, South Africa), $0.05 \mu \mathrm{M} \alpha$-naphthaleneacetic acid (NAA), 0.5 $\mu \mathrm{M}$ 6-benzylaminopurine (BAP), $0.4 \mu \mathrm{M}$ biotin, $0.2 \mu \mathrm{M}$ calcium pantothenate, $0.09 \mathrm{M}$ sucrose and $0.4 \%(w / v)$ Gelrite ${ }^{\circledR}$ (Polychem, Durban, South Africa). As soon as the axillary buds opened ( $\approx 5-10 \mathrm{~d}$ after culture initiation), they were excised from the nodal explants and transferred to fresh multiplication medium. After 4 weeks they were subcultured for another month, then elongated in MS nutrients, 0.05 $\mu_{\mathrm{M}}$ NAA, $0.05 \mu_{\mathrm{M}}$ IBA, $0.9 \mu_{\mathrm{M}}$ 6-furfurylaminopurine (FAP), $0.4 \mu \mathrm{M}$ biotin, $0.2 \mu \mathrm{M}$ calcium pantothenate, $0.07 \mathrm{M}$ sucrose and $0.4 \%$ (w/v) Gelrite ${ }^{\circledR}$. All cultures were grown under a $16-\mathrm{h}$ photoperiod at $66 \mu \mathrm{mol} \cdot \mathrm{m}^{-2} \cdot \mathrm{s}^{-1}$ photosynthetic photon flux density $(P P F D)$ provided by Biolux tubes (Osram L58W; Osram, Durban, South Africa) and $27{ }^{\circ} \mathrm{C}$ day/21 ${ }^{\circ} \mathrm{C}$ night (standard culture conditions). For both shoot multiplication and elongation, four shoots were cultured per bottle $(5 \times 7.5 \mathrm{~cm})$ containing $20 \mathrm{~mL}$ of medium. After 3-4 weeks of elongation, shoots $1.5-2 \mathrm{~cm}$ long were used for the rooting experiments and a single shoot was cultured per culture tube $(2.5 \times 10 \mathrm{~cm})$ containing $10 \mathrm{~mL}$ of rooting medium. All media used in this study were adjusted to $\mathrm{pH}$ 
5.8 with $1 \mathrm{~m} \mathrm{NaOH}$ and autoclaved for $20 \mathrm{~min}$ at $120^{\circ} \mathrm{C}$ and $121 \mathrm{kPa}$.

Rooting experiments. Factors influencing rooting in vitro were established using clone GN121 and the best protocol was then applied to clone GN107. The starting medium was $1 / 2$-strength MS nutrients, $0.4 \mu \mathrm{m}$ biotin, $0.2 \mathrm{~m}$ calcium pantothenate, $0.04 \mathrm{~m}$ sucrose and $0.4 \%(\mathrm{w} / \mathrm{v})$ Gelrite $^{\circledR}$. Shoots were incubated in the dark for $72 \mathrm{~h}$ at $\approx 25^{\circ} \mathrm{C}$ ), after which they were transferred to the standard culture conditions. The rooting period, including the $3 \mathrm{~d}$ of initial dark incubation, lasted 4 weeks. To facilitate rooting, the following variables were altered from the standard procedure.

Auxin application. Shoots were exposed to $98 \mu \mathrm{M}$ IBA for $24 \mathrm{~h}$ or $0.5,5$ and $12.3 \mu \mathrm{M}$ IBA for $72 \mathrm{~h}$ (pulse applications) and then to a hormone-free medium for $25 \mathrm{~d}$. In another treatment, shoots were exposed to 0.5 or 12.3 $\mu \mathrm{M}$ IBA in the medium for $28 \mathrm{~d}$ (chronic applications).

Medium strength. The effect of MS nutrient medium was tested at full-strength and at $1 / 2,1 / 3$, and 1/4-strength MS.

Calcium and magnesium concentrations. The 1/4-strength MS medium was modified to contain calcium (as $\mathrm{CaCl}_{2} \cdot 2 \mathrm{H}_{2} \mathrm{O}$ ) and magnesium (as $\mathrm{MgSO}_{4} \cdot 7 \mathrm{H}_{2} \mathrm{O}$ ) to $1 / 2$ and 3/4-strength of the concentrations in fullstrength MS by addition of $2.8 \mu \mathrm{M}$ and $5.5 \mu \mathrm{M}$ $\mathrm{Ca}$, and $3.8 \mu \mathrm{M}$ and $7.6 \mu \mathrm{M} \mathrm{Mg}$, respectively.

Light intensity and temperature. Light intensity and temperature were increased from $37 \mu \mathrm{mol} \cdot \mathrm{m}^{-2} \cdot \mathrm{s}^{-1} \mathrm{PPFD}$ and $23{ }^{\circ} \mathrm{C}$ day $/ 21{ }^{\circ} \mathrm{C}$ night for $7 \mathrm{~d}$ to $66 \mu \mathrm{mol} \cdot \mathrm{m}^{-2} \cdot \mathrm{s}^{-1} P P F D$ and $27{ }^{\circ} \mathrm{C}$ day $/ 21{ }^{\circ} \mathrm{C}$ night for $18 \mathrm{~d}$ under a $16-\mathrm{h}$ photoperiod.

Hardening-off of regenerated plantlets. All rooted shoots were transferred to a sterile, moistened potting mixture of 1 river sand : 9 pine bark (v/v) in $78 \mathrm{~cm}^{3}$ pots, enveloped in transparent plastic bags and kept in the greenhouse. After 1 week, the humidity of the microclimate was reduced by punching holes in the bags, which were then removed completely 1 week later. Plant survival was recorded after a 4-week hardening-off period in the greenhouse. The plantlets were then maintained under normal greenhouse conditions.

Statistical analysis. Twenty to 25 shoots were used per replicate, with three replications per treatment. Data were subjected to arcsine transformation and were tested for normal distribution by the Kolmogorov-Smirnoff test before statistical analysis, which was conducted with the Statgraphics Plus computer package (Statistical Graphic Corp., Rockville, Md.). A one-way analysis of variance was conducted at $P \leq 0.05$ and differences were contrasted using Duncan's multiple range test.

\section{Results and Discussion}

\section{Rooting experiments with clone GN121}

Auxin application. A single 24-h pulse treatment with $98 \mu \mathrm{M}$ IBA induced no rooting. Large amounts of callus were formed at basal ends of all shoots and most leaves abscised (data not shown). Similar responses were obtained in both macrocuttings and in vitro plants in the commercial laboratory of Mondi Forests (unpublished data). The percentage of rooting and callusing increased with exposure $(72 \mathrm{~h})$ to IBA at lower concentrations (Table 1). The reverse trend in rooting was observed with a chronic (i.e., $28 \mathrm{~d}$ ) application; best rooting $(28 \%)$ was obtained with $0.5 \mu \mathrm{M}$ IBA, despite the large number of shoots producing callus. Hence, subsequent investigations focused on attempts to eliminate callusing using the 0.5 $\mu_{\mathrm{M}}$ IBA chronic treatment.

Medium strength. The percentage of rooting increased and callus formation decreased as the nutrient concentration was reduced from full-strength ( $0 \%$ rooting, $100 \%$ callus) to $1 / 4$-strength MS (52\% rooting, $48 \%$ callus) (Table 2). Further, the roots obtained in $1 / 3$ and 1/4-strength MS were long and thick (32-37 cm in length) with well-developed lateral roots, whereas those produced in 1/2strength MS were stunted, averaging $14 \mathrm{~cm}$ in length (Fig. 1). In contrast, Warrag et al. (1990) reported that the level of basal minerals (1/4, 1/2, and full-strength MS nutrients) had little effect on the percentage of rooting of $E$. grandis $\times$ E. camaldulensis Dehn. and $E$. grandis $\mathrm{x}$ E. robusta $\mathrm{Sm}$. explants.

Calcium and magnesium concentrations. Increasing the concentrations of $\mathrm{Ca}^{2+}$ and $\mathrm{Mg}^{2+}$ to 3/4-strength of full MS medium did not improve rooting significantly, but all tested concentrations prevented callus proliferation (Table 3). However, when those macronutrients were tested separately at $1 / 2$ and 3/4strength, they had a negative effect on rooting. The ineffectiveness of adding calcium or magnesium alone reflected lack of absorption and/or assimilation of either ion in the other's absence.

Light intensity and temperature. A stepwise increase in light intensity and temperature from $37 \mu \mathrm{mol} \cdot \mathrm{m}^{-2} \cdot \mathrm{s}^{-1} P P F D$ and $23{ }^{\circ} \mathrm{C}$ day $/ 21^{\circ} \mathrm{C}$ night to $66 \mu \mathrm{mol} \cdot \mathrm{m}^{-2} \cdot \mathrm{s}^{-1} P P F D$ and $27{ }^{\circ} \mathrm{C}$ day $/ 21{ }^{\circ} \mathrm{C}$ night increased rooting to $75 \%$ (Table 3 ) and no callusing occurred. The roots were well-formed (Fig. 1). The step-

Table 1. Effects of pulse and chronic applications of IBA on in vitro rooting and callusing of $E$. grandis $\mathrm{x}$ E. nitens (GN121) shoots on 1/2strength MS medium. Shoots were kept in darkness for an initial $72 \mathrm{~h}$ followed by a $16-\mathrm{h}$ photoperiod at $66 \mu \mathrm{mol} \cdot \mathrm{m}^{-2} \cdot \mathrm{s}^{-1} P P F D$ and $27^{\circ} \mathrm{C}$ day $/ 21^{\circ} \mathrm{C}$ night.

\begin{tabular}{lcr}
\hline $\begin{array}{l}\text { IBA } \\
(\mu \mathrm{M})\end{array}$ & $\begin{array}{c}\text { Rooting } \\
(\%)\end{array}$ & $\begin{array}{r}\text { Callusing } \\
(\%)\end{array}$ \\
\hline \multicolumn{3}{c}{} \\
0.5 & Pulse applications $(72 \mathrm{~h})$ \\
5.0 & $6.0 \mathrm{a}^{\mathrm{z}}$ & $8.0 \mathrm{a}$ \\
12.3 & $8.0 \mathrm{a}$ & $38.0 \mathrm{~b}$ \\
\multicolumn{3}{c}{} \\
0.5 & $24.0 \mathrm{~b}$ & $44.0 \mathrm{~b}$ \\
12.3 & Chronic applications $(28 \mathrm{~d})$ \\
\hline
\end{tabular}

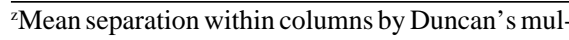
tiple range test, $P \leq 0.05$. Values represent means of three replications of 25 shoots each. Results were recorded after $28 \mathrm{~d}$. wise increase in light intensity and temperature may have facilitated the translocation of endogenous auxin synergists (e.g., phenols) and carbohydrates to stem bases, as shown by Wang (1992). In addition, Baadsmand and Andersen (1984) found that under high irradiance $\left(38 \mathrm{~W} \mathrm{~m}^{-2}\right)$ and constant air temperature $\left(27^{\circ} \mathrm{C}\right)$, the leaf temperature of pea (Pisum sativum L.) cuttings was high $\left(34^{\circ} \mathrm{C}\right)$; they suggested that an increase in light intensity and tissue temperature increased the polarity of auxin transport.

\section{Application of the developed protocol to clone GN107}

When the protocol used for GN121 was applied to clone GN107, similar rooting responses were observed. Under the best culture conditions tested for GN121, the percentage of rooting of clone $\mathrm{GN} 107$ was lower than that of GN121 (65\% vs. 75\%) (Table 3). Rasmussen (1991) and Willyams et al. (1992) reported similar variations in rooting rates among $E$. nitens clones.

Table 2. Effect of strength of MS medium on in vitro rooting and callusing of $E$. grandis $\times E$. nitens (GN121) shoots. The medium was supplemented with $0.5 \mu \mathrm{M}$ IBA and shoots were kept in darkness for an initial $72 \mathrm{~h}$ followed by a $16-\mathrm{h}$ photoperiod at $66 \mu \mathrm{mol} \cdot \mathrm{m}^{-2} \cdot \mathrm{s}^{-1} P P F D$ and $27^{\circ} \mathrm{C}$ day $/ 21^{\circ} \mathrm{C}$ night.

\begin{tabular}{lcr}
\hline $\begin{array}{l}\text { Strength of } \\
\text { MS medium }\end{array}$ & $\begin{array}{c}\text { Rooting } \\
(\%)\end{array}$ & $\begin{array}{c}\text { Callusing } \\
(\%)\end{array}$ \\
\hline Full & $0.0 \mathrm{a}^{\mathrm{z}}$ & $100.0 \mathrm{~d}$ \\
$1 / 2$ & $28.0 \mathrm{~b}$ & $72.0 \mathrm{c}$ \\
$1 / 3$ & $36.0 \mathrm{bc}$ & $60.0 \mathrm{~b}$ \\
$1 / 4$ & $52.0 \mathrm{~d}$ & $48.0 \mathrm{a}$ \\
\hline
\end{tabular}

${ }^{2}$ Mean separation within columns by Duncan's multiple range test, $P \leq 0.05$. Values represent means of three replications of 25 shoots each. Results were recorded after $28 \mathrm{~d}$.

Table 3. Effects of additional calcium and magnesium on in vitro rooting of shoots of $E$. grandis $\mathrm{x}$ E. nitens clones GN121 and GN107 on 1/4 strength MS medium under two light intensity and temperature regimes following an initial 72-h dark period.

\begin{tabular}{|c|c|c|c|}
\hline Clone & $\begin{array}{c}\text { Medium } \\
\text { modifications }\end{array}$ & $\begin{array}{c}\text { Rooting } \\
(\%)\end{array}$ & $\begin{array}{c}\text { Callusing } \\
(\%)\end{array}$ \\
\hline \multicolumn{4}{|c|}{$\begin{array}{l}66 \mu \mathrm{mol} \cdot \mathrm{m}^{-2} \cdot \mathrm{s}^{-1} \mathrm{PPFD} \text { and } \\
7{ }^{\circ} \mathrm{C} \text { day } / 21{ }^{\circ} \mathrm{C} \text { night for } 25 d^{z}\end{array}$} \\
\hline \multirow[t]{7}{*}{ GN121 } & None & $52.0 \mathrm{~cd}^{\mathrm{y}}$ & $48.0 \mathrm{~b}$ \\
\hline & $1 / 2 \mathrm{Ca}$ & $35.0 \mathrm{bc}$ & $0.0 \mathrm{a}$ \\
\hline & $3 / 4 \mathrm{Ca}$ & $25.0 \mathrm{ab}$ & $0.0 \mathrm{a}$ \\
\hline & $1 / 2 \mathrm{Mg}$ & $15.0 \mathrm{a}$ & $0.0 \mathrm{a}$ \\
\hline & $3 / 4 \mathrm{Mg}$ & $20.0 \mathrm{ab}$ & $0.0 \mathrm{a}$ \\
\hline & 3/4 Ca \& 3/4 Mg & $53.0 \mathrm{~d}$ & $0.0 \mathrm{a}$ \\
\hline & \multicolumn{3}{|c|}{$\begin{array}{l}37 \mu \mathrm{mol} \cdot \mathrm{m}^{-2} \cdot \mathrm{s}^{-1} \mathrm{PPFD} \text { and } \\
23^{\circ} \mathrm{C} \text { day } / 21{ }^{\circ} \mathrm{C} \text { night for } 7 \mathrm{~d}^{x} \\
\text { ereafter standard conditions for } 18 \mathrm{~d}\end{array}$} \\
\hline GN121 & $3 / 4 \mathrm{Ca} \& 3 / 4 \mathrm{Mg}$ & $75.0 \mathrm{e}$ & $0.0 \mathrm{a}$ \\
\hline GN107 & $3 / 4 \mathrm{Ca} \& 3 / 4 \mathrm{Mg}$ & $65.0 \mathrm{de}$ & $0.0 \mathrm{a}$ \\
\hline
\end{tabular}

${ }^{\mathrm{z}}$ Standard environmental conditions.

'Mean separation within columns by Duncan's multiple range test, $P \leq 0.05$. Values represent means of three replications of 20 shoots each (control, $\mathrm{n}=$ $25)$. Results were recorded after $28 \mathrm{~d}$.

${ }^{x}$ Modified environmental conditions. 


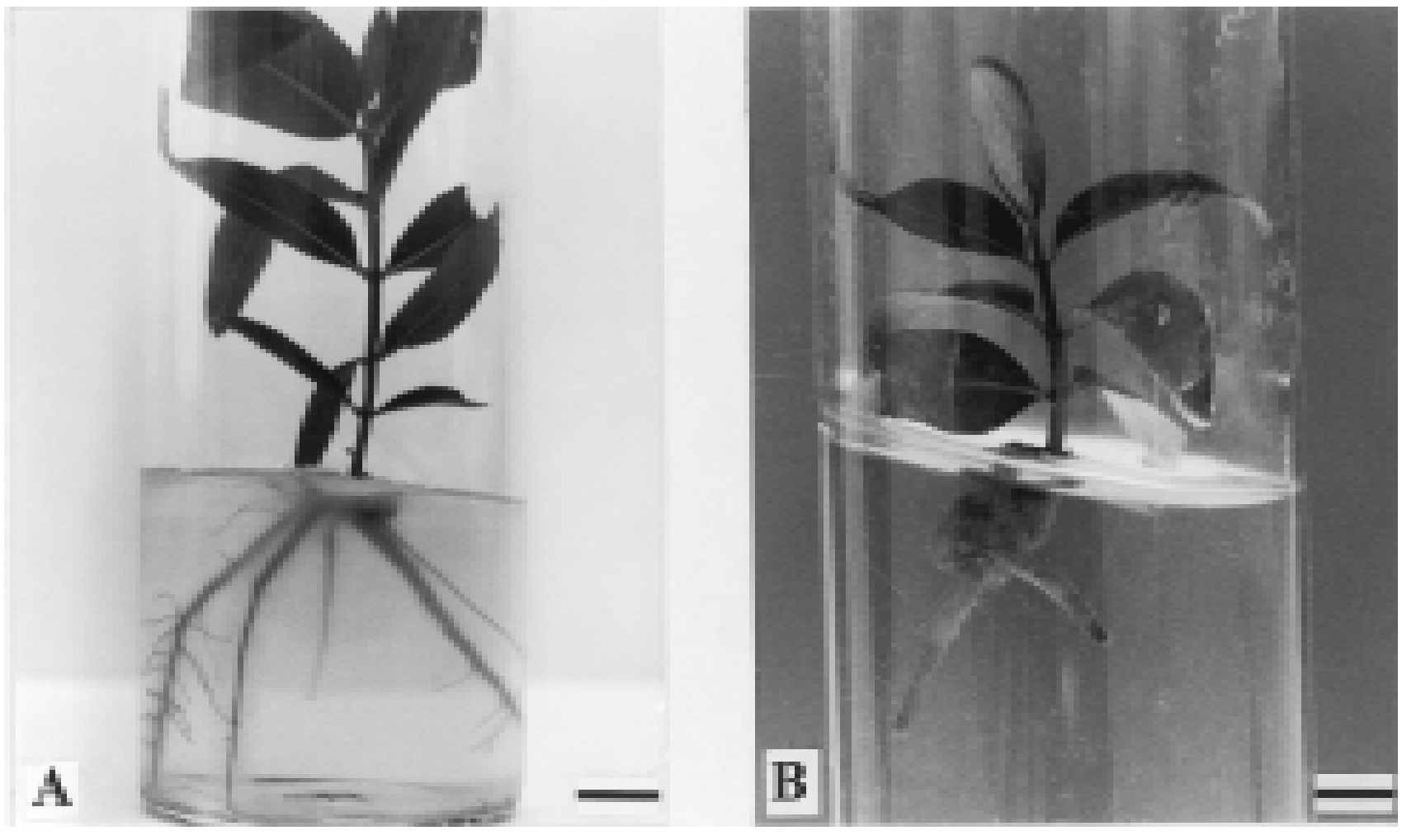

Fig. 1. Adventitious root induction in micropropagated shoots of E. grandis $\times$ E. nitens clone GN121 cultured for $28 \mathrm{~d}$ on $(\mathbf{A}) 1 / 4-\mathrm{strength}$ MS $($ bar $=5.4 \mathrm{~cm})$ and $($ B $) 1 / 2$-strength MS $($ bar $=4 \mathrm{~cm}$ ) medium supplemented with $0.5 \mu \mathrm{M}$ IBA.

Hardening-off of regenerated plantlets. At the end of rooting period, when plantlets were transferred to greenhouse conditions, survival of GN121 was higher than that of clone GN107 ( $78 \%$ vs. $58 \%$ ). Roots could have been damaged during potting, thus reducing the survival rate of micropropagated plantlets. To avoid this, Warrag et al. (1990) have recommended that rooted shoots should be transferred to ex vitro conditions as soon as a few roots are produced.

In conclusion, by modifying medium and culture conditions, a protocol was established for in vitro rooting of two clones of $E$. grandis $x E$. nitens. The most important factors that influenced rooting were light intensity and temperature. However, addition of calcium and magnesium had a beneficial effect by preventing callus formation at the bases of shoots. On average, shoot multiplication yielded 10 shoots per explant in 4 weeks. In theory, one million shoots may therefore be produced after seven subcultures. With the rooting and hardening-off success reported here, this translates to $\approx 585,000(\mathrm{GN} 121)$ and 377,000 (GN107) plants from one axillary bud within a year. If similar results can be obtained in the commercial laboratory, some of these plants can be used to establish clonal hedges and others for afforestation in cold, dry marginal areas.

\section{Literature Cited}

Baadsmand, S. and A.S. Andersen. 1984. Transport and accumulation of indole-3-acetic acid in pea cuttings under two levels of irradiance. Physiol. Plant. 61:107-113.

Blomstedt, C., J. Cameron, P. Whiteman, and S.F. Chandler. 1991. Micropropagation of juvenile Eucalyptus regnans (mountain ash). Aust. J. Bot. 39:179-186

Denison, N.P. and J.E. Kietzka. 1993. The use and importance of hybrid intensive forestry in South Africa. South Afr. For. J. 165:55-61.

February, E.C., W.D. Stock, W.J. Bond, and D.J. Le Roux. 1995. Relationships between water availability and selected vessel characteristics in $\mathrm{Eu}$ calyptus grandis and two hybrids. Intl. Assoc. Wood Anatomists J. 16:269-276.

Furze, M.J. and C.F. Cresswell. 1985. Micropropagation of Eucalyptus grandis and nitens using tissue culture techniques. South Afr. For. J. 135:20-23.

Jones, N.B. and J. van Staden. 1994. Micropropagation and establishment of Eucalyptus hybrids. South Afr. J. Bot. 60:123-126.
Le Roux, J.J. and J. van Staden. 1991a. Micropropagation of Eucalyptus species. HortScience 26:199_ 200.

Le Roux, J.J. and J. van Staden. 1991b. Micropropagation and tissue culture of Eucalyptus-A review. Tree Physiol. 9:435-477.

Martin, C. 1985. Plant breeding in vitro. Endeavour (N.S.) 9:81-86.

Murashige, T. and F. Skoog. 1962. A revised medium for rapid growth and bioassays with tobacco tissue cultures. Physiol. Plant. 15:473-497.

Rasmussen, G.F. 1991. Micropropagation of E. nitens and hybrid clones, p. 106-109. In: C. Dean (ed.). Proc. $11^{\text {th }}$ Res. Working Group 1. Forest Genetics, Coonawarra, South Australia.

Wang, Q. 1992. The effect of light, darkness and temperature on micropropagation of the pear rootstock BP10030. J. Hort. Sci. 67:869-876.

Warrag, E.I., M.S. Lesney, and D.L. Rockwood. 1990. Micropropagation of field-tested superior Eucalyptus grandis hybrids. New For. 4:67-79.

Willyams, D., P. Whiteman, J. Cameron, and S.F. Chandler. 1992. Inter-and intra-family variability for rooting capacity in micropropagated Eucalyptus globulus and Eucalyptus nitens, p. 195-202. In: Association Forêt-Cellulose/ International Union of Forestry Research Organizations (AFOCEL/IUFRO) Symp. on Mass Production Technol. For Genetically Improved Fast Growing Tree Species. Bordeaux, France. 